\title{
De integración e identidades. Portugueses en las cofradías limeñas, 1571-1680/
}

\author{
Integration and Identities. \\ Portuguese Residents in the Lima Brotherhoods, 1571-1680
}

\author{
Gleydi Sullón Barreto \\ ORCID iD: http://orcid.org/0000-0003-3789-1495 \\ Universidad Alas Peruanas
}

El objeto de este artículo es identificar la capacidad de integración de los portugueses residentes en Lima entre 1571-1680, a través del análisis de los vínculos creados con las cofradías y hermandades de la ciudad. No hubo en la Lima colonial asociaciones de carácter nacional que agrupasen de forma exclusiva a los inmigrantes portugueses, como sí ocurrió, en cambio, en la España Moderna. De esta manera, el grupo extranjero que nos ocupa, puso de manifiesto su intención de procurar diversas estrategias para integrarse a la tierra de adopción.

Palabras Clave: Lima Colonial; Siglos XVI y XVII; Portugueses; Cofradías; Integración; Identidades; Vínculos Sociales; San Antonio de Padua.

The objective of this article is to identify the extent of integration of Portuguese residents in Lima between 1571 and 1680 through the analysis of the links they created with the confraternities and brotherhoods of the city. There were no national associations in Colonial Lima that would have exclusively accommodated the Portuguese immigrants, as there had been in Early Modern Spain. The Portuguese therefore chose other diverse institutions —-some of Spanish foundation-, revealing a sense of openness of this foreign group toward their adopted land.

KeYwords: Colonial Lima; XVI and XVII Century; Portuguese; Confraternity; Integration; Identities, Social Links, San Antonio of Padua.

Copyright: (C) 2018 CSIC. Este es un artículo de acceso abierto distribuido bajo los términos de la licencia de uso y distribución Creative Commons Reconocimiento 4.0 Internacional (CC BY 4.0). 


\section{Introducción $^{1}$}

En los últimos años se está asistiendo a una renovación en los estudios sobre la presencia de los portugueses en el Perú virreinal. Si antes los lusos eran estudiados dentro de la categoría de judaizantes, recientes investigaciones vienen demostrando que no todos judaizaron. Es decir, hubo los que se comportaron como auténticos cristianos y habrían llegado a conformar los estratos medios de la sociedad. ${ }^{2}$

Este artículo trata precisamente de aquel grupo de portugueses que se ubicó en Lima entre 1571 y 1680 y que probablemente vivió con autenticidad su fe cristiana. Estos portugueses asentados en Lima superaron el supuesto círculo endogámico en el que la historiografía tradicional los había colocado y, en definitiva, pensaron, sintieron y se comportaron como otros limeños más. Además, habrían procurado diversas estrategias para integrarse al suelo que los adoptó: buscaron el matrimonio con una natural del reino, procuraron el traslado de toda la familia y su asistencia en el hospital de los españoles de San Andrés, optaron también por incorporarse en las hermandades y cofradías limeñas, no tanto como una forma de expresar su religiosidad sino, también, como una forma de integración. Esto nos permite alcanzar una prueba evidente de que el colectivo analizado deseaba permanecer largamente en la ciudad. ${ }^{3}$

Precisamente, el objeto de este artículo es identificar la capacidad de integración de los portugueses residentes en Lima entre 1571-1680, a través del análisis de los vínculos creados con las cofradías, hermandades

1 La versión preliminar de este artículo fue un breve epígrafe titulado «Las cofradías como forma de integración en la sociedad» incluido en mi tesis doctoral presentada en la Universidad Complutense de Madrid en marzo de 2014 (disponible en http://eprints.ucm.es/27850/1/T35619.pdf; véase capítulo 2, epígrafe 2.4, 122-127), y este mismo epígrafe se publicó en Sullón Barreto, 2016, 109-114. No obstante, la versión que se presenta ahora se ve enriquecida tanto en la estructura del trabajo como en la incorporación de nuevas fuentes inéditas. Se incluye como novedad el perfil biográfico de los portugueses cofrades y una breve referencia a la figura de san Antonio de Padua en el contexto limeño. Agradezco a los profesores Juan Ignacio Pulido Serrano y Jorge Rosales Aguirre por la generosidad de su tiempo en la lectura del texto y por las observaciones, sugerencias y cuestiones planteadas. A Sonia Suyón, por la corrección de estilo. A Héctor Santiago Cazull por la revisión del abstract. Asimismo, expreso mi agradecimiento a los evaluadores anónimos del Anuario de Estudios Americanos por sus observaciones.

2 Véase al respecto Ventura, 2005. Sullón Barreto, 2016.

3 De acuerdo con la legislación indiana la categoría que correspondió a los portugueses dentro de la monarquía hispánica fue de «extranjeros», incluso en los años de unión de coronas y aun cuando algunos se hubieren naturalizado y avecindado. Para una aproximación al concepto de ciudadanía universal romana por parte de los juristas y teóricos de finales del siglo XVI en la definición de los naturales del reino frente a los extranjeros, véase Gil, 2016. 
o esclavitudes de la ciudad. ${ }^{4}$ De los 176 casos de portugueses conocidos en este periodo de tiempo, tenemos que 38 de ellos habrían pertenecido a una o más cofradías, tanto de las fundadas en Lima como en el puerto de El Callao. ¿Qué razones habrían llevado a este colectivo extranjero a ingresar a cofradías, hermandades o esclavitudes limeñas? Es probable que haya influido el mensaje cristiano de ese tiempo que predicaba la salvación del alma a través de diversos medios y es probable también que, para la mayoría de los casos estudiados, el ingreso a una de estas cofradías haya representado una suerte de estrategia de integración en una ciudad extraña.

Para el desarrollo del tema conviene tener en cuenta dos aspectos. El primero está referido a la cuestión religiosa, es sabido que muchos de los portugueses que llegaron al virreinato fueron acusados de judaizar, por tanto su ingreso en cualquiera de las hermandades o cofradías limeñas podía ser interpretado por los inquisidores como un disimulo encubridor, la manifestación externa de una práctica cristiana forzada por las circunstancias y, en realidad, falsa. ${ }^{5} \mathrm{El}$ segundo aspecto se halla relacionado con el tema del vínculo nacional. A diferencia de lo sucedido en la España Moderna (donde al parecer la cofradía de San Antonio habría procurado conservar los rasgos culturales propios de los portugueses establecidos en Castilla o en las diversas localidades de las islas Canarias ${ }^{6}$ ), en Lima no hubo cofradías ni hermandades exclusivamente para portugueses. Si bien la cofradía de San Antonio atrajo especialmente a algunos de los portugueses limeños, en realidad este santo de fama universal gozó de popularidad y devoción en todo el ámbito limeño, al margen del origen, naturaleza o etnia de sus habitantes.

Conviene mencionar que para el cumplimiento del objetivo planteado fueron consultados los fondos notariales del Archivo General de la Nación de Lima. La información aportada por esta fuente ha permitido identificar un número importante de portugueses que, en los años seleccionados para

4 El modelo de análisis aplicado fue el de los vínculos interpersonales que ha permitido una aproximación a las relaciones establecidas no solo entre los individuos lusos, sino también entre estos y las corporaciones religiosas de la ciudad. Sobre este modelo, véase Ponce y Amadori, 2008.

5 Véase carta fechada en Lima a 18 de mayo de 1636, apud Medina, 1887, II, 70.

6 Pulido Serrano, 2006. Aunque conviene matizar, de acuerdo con el autor, que si bien las cofradías de San Antonio habrían procurado, en aquellas tierras, representar los rasgos identitarios de los hijos de la nación lusa, «ello no significa que los portugueses repartidos por España se integraran en ellas, ya que estas tuvieron un marcado carácter corporativo estamental, reuniendo sobre todo a la nobleza, clero, mercaderes y algún que otro artesano cualificado de esta nacionalidad. Así, la mayor parte de los portugueses, que no pertenecían a estos grupos sino a otros mucho más humildes, o quedaron fuera de cualquier cofradía o se integraron en otras de alcance parroquial o profesional». Agradezco al doctor Ignacio Pulido por esta pertinente observación. 
este estudio, se hallaban afincados en la capital del virreinato peruano. La mayoría de estos portugueses hizo testamento y ha sido precisamente esta fuente la que nos ha revelado los vínculos y las conexiones de este colectivo extranjero con las cofradías limeñas. Pero, si bien la fuente notarial permite trazar el itinerario seguido por los portugueses en cada una de las cofradías citadas, aun sigue faltando en el Perú un estudio específico de esas asociaciones religiosas, sobre todo para el siglo XVII. ${ }^{7}$ Las páginas que siguen intentan constituir un aporte al estudio de los extranjeros en el Perú virreinal y a las fórmulas que hallaron para incorporarse a la nueva sociedad, donde, sin duda, las cofradías y hermandades representaron para estas gentes uno de los medios posibles de integración.

\section{Perfil biográfico de los portugueses cofrades}

En este epígrafe se procura una aproximación al perfil biográfico de los portugueses que estuvieron vinculados con las cofradías limeñas. Se valora también la situación económica de los cofrades lusos, pues si bien estas asociaciones religiosas contemplaron en sus estatutos la posibilidad de brindar ayuda espiritual o asistencial a sus miembros, el ingreso y la posterior permanencia en cualquiera de ellas suponía un costo o una inversión que no todos estuvieron en condición de pagar.

De los 196 portugueses localizados en Lima entre los años de 1571 a $1680,{ }^{8} 176$ dictaron testamento o dejaron carta poder para testar. En este trabajo se ha considerado como universo de estudio estos 176 nombres de

7 Si bien el Archivo Arzobispal de Lima y el Archivo Histórico de la Beneficencia Pública de Lima conservan un fondo dedicado a las cofradías, en su mayoría la cronología de estos documentos corresponde al siglo XVIII, y son menos las referencias a los siglos XVI o XVII. Por otro lado, no se conservan en ninguno de esos dos archivos las constituciones de las cofradías citadas en este trabajo. Esta realidad queda reflejada en la escasa producción bibliográfica sobre el tema, pues se ha podido comprobar que no existe un estudio completo de las cofradías limeñas para los años de 1571 a 1680. Agradezco a Kelly Montoya por la información facilitada al respecto. Para una aproximación al tema de las cofradías, aunque con pocas referencias al siglo XVII, véase: Vargas Ugarte, 1953, t. I. Celestino y Meyers, 1981, 114-124. Lohmann, 1990. Garland, 1994. Paniagua, 1995. Vega Jácome, 1999. Lévano, 2002. Puente Brunke, 2002. Corilla, 2002. Lévano y Montoya, 2010. Campos, 2014.

8 La elección de esta cronología, que incorpora como elemento principal los años de unión de España y Portugal, obedece al interés de evaluar el comportamiento de los lusos en Lima algunos años antes de la unión de reinos, durante esta y después de la separación, pues si bien la llegada de los portugueses disminuyó después de 1640, en lo sustancial el proceso de separación afectó muy poco a los inmigrantes lusos que ya se hallaban establecidos en Lima. Para una reflexión reciente sobre los cortes cronológicos del Portugal hispano o filipino, Valladares, 2016, 16-17. 
portugueses que, además de haber coincidido en Lima en un periodo de tiempo determinado, tuvieron como rasgo común el haber dictado testamento. La expresión de las últimas voluntades permite conocer uno de los espacios más personales y sinceros de los otorgantes, de cara a la muerte. ${ }^{9}$ La profesión de fe, la elección del lugar de sepultura o las misas de sufragio precisadas en el testamento remiten no solo a la intención de alcanzar la salvación del alma, sino también a los afectos y devociones particulares. De los casos conocidos, 78 portugueses estuvieron vinculados de una u otra forma con las cofradías y hermandades limeñas $(44,31 \%)$, pero solo $38 \mathrm{de}$ ellos se integraron propiamente como hermanos o cofrades $(21,59 \%) \cdot{ }^{10} \mathrm{Del}$ ingreso de los lusos en este tipo de asociaciones durante el periodo analizado, la referencia más antigua de las que hemos recogido corresponde a Rodrigo Paes, quien en 1588 pertenecía ya a la cofradía de San Antonio de Padua, fundada en el limeño convento de San Francisco. ${ }^{11}$

Por su situación socio-profesional destacaron los mercaderes $(31,57 \%)$ y los productores artesanales $(23,68 \%)$, hubo también, entre otros, oficiales marinos $(10,52 \%)$, los dedicados a la vida consagrada $(10,52 \%)$, labradores o propietarios de tierras $(5,26 \%)$ y soldados $(5,26 \%)$. Pertenecían en su mayoría a los estratos medios de la sociedad, destacando entre todos, como el mayor propietario, el lisboeta Antonio de Abendaño, quien en 1597 se hallaba asentado —en compañía de su mujer Catalina Ortiz - en el barrio de San Diego del puerto de El Callao. Este luso, dedicado a la administración de sus tres chácaras y a la actividad comercial, se había integrado «en todas las cofradías de este puerto», entre otras: Rosario, Santísimo Sacramento, Soledad y la Veracruz. ${ }^{12}$ Esta realidad, además de sus cuantiosas propiedades, nos da luces sobre su acomodada posición económica en tanto el ingreso a una cofradía suponía un costo de entrada y el pago de cuotas periódicas, bajo el concepto de limosnas, que no todos los portugueses podían asumir. No obstante, creemos que no existió una relación directa entre la situación económica del portugués y su pertenencia a una cofradía, pues hubo portugueses cuya

9 El 84,48 \% de la muestra analizada habría testado estando enfermo.

10 En la deducción de estos porcentajes se ha considerado como universo los 176 portugueses que dictaron testamento; de ese número se cuentan siete mujeres, de las que únicamente tres fueron cofrades.

11 Bienes de difuntos: Rodrigo Paes, Traslado de testamento, Lima, 29 de julio de 1588, Archivo General de Indias de Sevilla (AGI), Contratación, 257B, n. 3, r. 1, 7r-12v.

12 Bienes de difuntos: Antonio de Abendaño, Traslado de testamento, Puerto de El Callao, 2 de marzo de 1597, AGI, Contratación, 295, n. 1, r. 5, 12r-25r. 
hacienda superó los 180000 pesos de a ocho reales — caso del clérigo Manuel Correa y del mercader Joan de Nolete $-{ }^{13}$ y, pese a la solvencia económica, no se integraron a cofradía alguna. En cambio, encontramos otros casos como el de Bartolomé Rodrigues Paes, oficial sedero, que aunque declaró no tener «al presente bienes ningunos ni derechos y acciones en este reino ni en otra parte», había ingresado hasta en dos cofradías de la ciudad. ${ }^{14}$ De todas formas, la participación de los lusos limeños, como miembros o cofrades, había quedado reservada a poco más de la quinta parte del colectivo analizado.

Al parecer, estos lusos habrían conformado la población estable de la ciudad. Así tenemos que de los casos conocidos el 59,51\% se situó entre los casados y viudos y el $55 \%$ llevaba residiendo en Lima o en el puerto de El Callao un tiempo superior a los 16 años. Cierto es que la mayoría de ellos vivió en situación de alquiler, solo el 23,68 \% de los portugueses cofrades había invertido en la compra de casas, tiendas y solares. Procedentes de regiones muy diversas de Portugal (Lisboa, Oporto, Setúbal, islas Azores, Algarbe o Santaré) eligieron por zonas de residencia en Lima, principalmente, las parroquias de Santa Ana, San Sebastián, iglesia Mayor y San Lázaro. En El Callao, entretanto, hubo preferencias por la parroquia de San Diego. La elección de las zonas de residencia en Lima resulta un indicador acerca de la capacidad de integración de los portugueses en la Ciudad de los Reyes, donde se observa que no conformaron un solo grupo cerrado ni ocuparon una única parroquia, sus actividades se habrían cumplido en los distintos ambientes de la ciudad y seguramente en una pacífica y fluida comunicación con los naturales del reino, con gente de origen étnico distinto, y con otros extranjeros. Ello, sin embargo, no impidió el hecho de que algunos conservaran el recuerdo de la patria de origen. El 44,73 \% de los casos conocidos contempló en el testamento algunas mandas de limosnas a parientes e instituciones en Portugal, el 7,89 \% conservó cartas y libros en lengua portuguesa, y el 2,63 \% contó entre sus bienes con cuadros, lienzos e imágenes de bulto que evocaban la figura del santo lisboeta, ${ }^{15}$ lo que sugiere que estos portugueses, aunque

13 Testamento del licenciado Manuel Correa, Lima, 11 de abril de 1623, Archivo General de la Nación de Lima (AGN), Prot. Not. 1740, Diego Sánchez Vadillo (1619-1623), 706r-724r. Testamento de Joan de Nolete, Lima, 17 de octubre de 1656, AGN, Prot. Not. 1038, Miguel López Varela (1656), $1818 \mathrm{r}-1879 \mathrm{v}$, respectivamente.

14 Testamento de Bartolomé Rodrigues Paes, Lima, 8 de abril de 1617, AGN, Prot. Not. 181, Cristóbal de Barrientos (1604-1618), 1198r-1200v.

15 Estos porcentajes se han deducido de los 38 portugueses cofrades que tenemos recogidos. 
integrados en Lima, como es comprensible, no olvidaron sus raíces ni los primeros afectos.

Finalmente se recogen dos datos más sobre el colectivo analizado. El primero referido al aspecto cultural-educativo y el segundo a la cuestión religiosa. Aunque fueron pocos los portugueses que estuvieron en posesión de libros de lectura, es probable que en su mayoría supieran leer y escribir, ya que el 10,53\% de los casos conocidos había cursado algún tipo de estudios —clérigos y cirujanos, especialmente_- el 57,89 \% dispuso de libros de cuentas o memorias donde llevaban el registro de sus deudas a favor o en contra, ${ }^{16}$ y el 55,26 \% supo firmar en el testamento. ${ }^{17}$ Por otro lado, la descripción de sus bienes muebles, de los utensilios de cocina y de su ropa de vestir — donde hubo un claro predominio de la ropa de Castilla - evidencia que estos lusos participaron, al igual que los demás limeños, de las preferencias, los gustos y la moda de la época, sin señas de una identidad nacional propia. En cuanto a la cuestión religiosa, hubo dos portugueses, Sebastián Delgado y Antonio de los Santos, que sufrieron prisión por razón de su supuesto judaísmo, aunque finalmente la justicia los exculparía: en el primer caso porque la causa se suspendió y en el segundo por falso testimonio, ${ }^{18}$ esto significa que nuestros lusos cofrades habrían conformado el grupo de los practicantes cristianos sinceros.

\section{Integración de los portugueses como miembros cofrades}

De las 37 cofradías que se citan en los documentos, ${ }^{19}$ los lusos limeños se habían incorporado en 25 de ellas, siendo las más populares las de Ánimas, Soledad, San Antonio, Rosario y el Santo Cristo. Y habrían recibido

16 Por lo general fueron los mercaderes los que llevaban estos libros de cuentas, como fue el caso del bodeguero Manuel Caballero de Ataide, quien en 1658 declaró tener «un libro en que asiento las cosas tocantes a tratos y contratos del ejercicio de bodeguero». Testamento de Manuel Caballero de Ataide, Lima, 25 de septiembre de 1658, AGN, Prot. Not. 185, Antonio de Barros (1653-1675), 770r-773r.

17 Los que no firmaron el testamento no lo hicieron por hallarse graves o «por no saber escribir».

18 Relaciones de causas y autos de fe del Tribunal de la Inquisición de Lima, 1639-1666, Archivo Histórico Nacional de Madrid (AHN), Inquisición, libro 1031, 51v. Prisión, secuestro e inventario de bienes de Antonio de los Santos, Lima, 19 de abril de 1636, AGN, Santo Oficio-Contencioso (SO-CO), 60-443, respectivamente. Para una descripción detallada del auto de fe que se celebró en Lima en 1639, donde se da cuenta de algunos de los portugueses (sospechosos de judaizar) citados en este trabajo, véase Montesinos, 1639.

19 Para esta clasificación se ha tenido en cuenta el nombre de la cofradía independientemente de su lugar de fundación (en Lima o en el puerto de El Callao; en una iglesia parroquial o en un convento). 
poco menos del $60 \%$ de elecciones (véase gráfico 1). La relación completa de las cofradías de las que formaron parte los portugueses de la muestra se incluye en el cuadro $1 .^{20}$ Vale mencionar que con excepción de la cofradía de Ánimas (de carácter parroquial), las dos siguientes se habían fundado en el convento de San Francisco, y las dos últimas, en Santo Domingo y San Agustín respectivamente.

\section{GRÁFICO 1}

PRINCIPALES COFRADÍAS QUE INTEGRARON A LOS PORTUGUESES DE LIMA

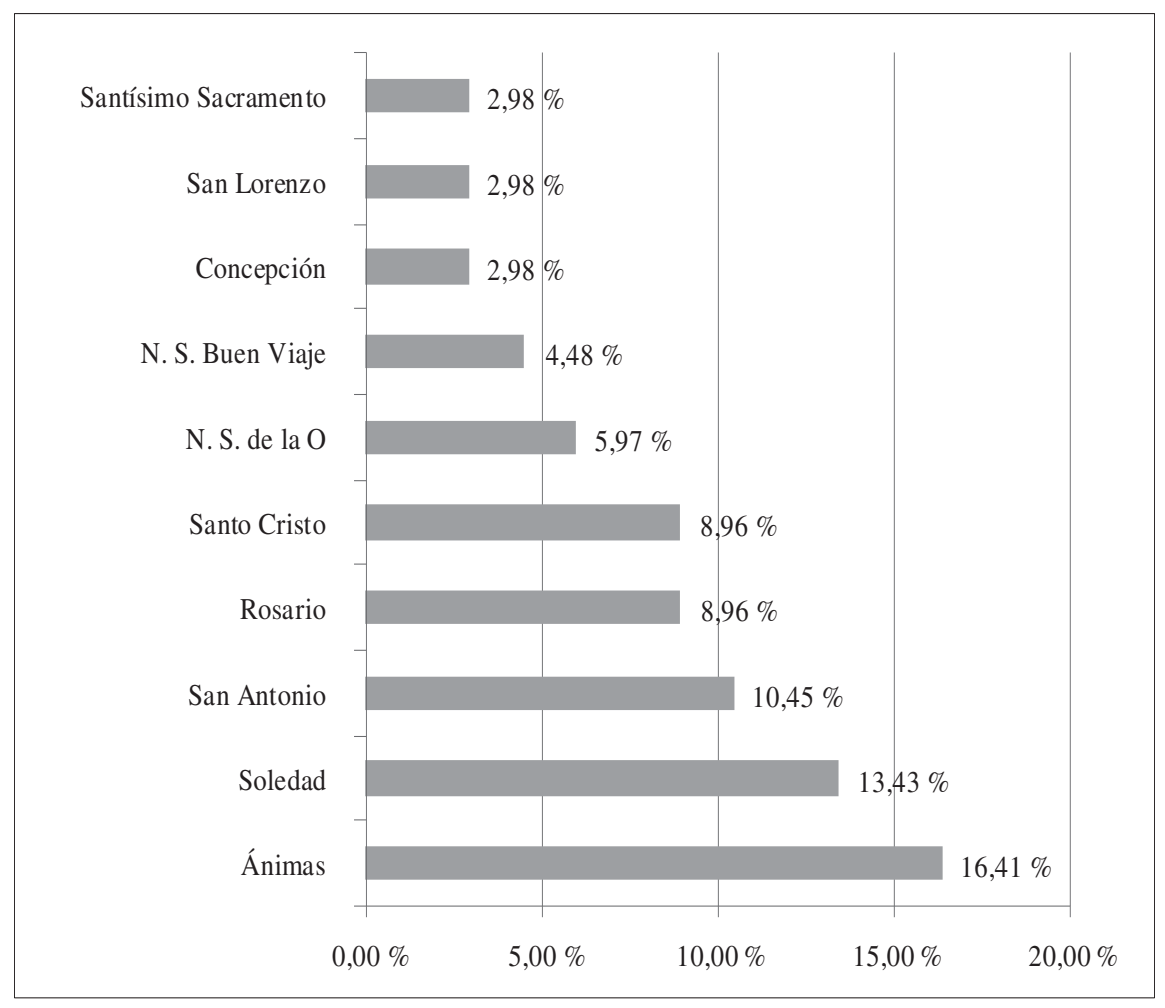

20 Fuentes del gráfico y del cuadro: Elaboración propia con información obtenida de la fuente notarial de 38 casos conocidos, que representa el número de los portugueses cofrades. Los porcentajes representan el número de elecciones, toda vez que hubo portugueses que se integraron en más de una cofradía. 
DE INTEGRACIÓN E IDENTIDADES. PORTUGUESES EN LAS COFRADÍAS LIMEÑAS

\section{CuAdro 1}

RELACIÓN DE COFRADÍAS EN LAS QUE SE INTEGRARON LOS PORTUGUESES DE LIMA

\begin{tabular}{|c|c|c|}
\hline Nombre de la cofradía & Número de elecciones & Porcentaje \\
\hline Ánimas & 11 & 16,41 \\
\hline Soledad & 9 & 13,43 \\
\hline San Antonio & 7 & 10,45 \\
\hline Rosario & 6 & 8,96 \\
\hline Santo Cristo & 6 & 8,96 \\
\hline Nuestra Señora de la O & 4 & 5,97 \\
\hline Nuestra Señora del Buen Viaje & 3 & 4,48 \\
\hline Concepción salvoconducto & 2 & 2,98 \\
\hline San Lorenzo & 2 & 2,98 \\
\hline Santísimo Sacramento & 2 & 2,98 \\
\hline Veracruz & 1 & 1,49 \\
\hline Nuestra Señora de Aguas Santas & 1 & 1,49 \\
\hline Nuestra Señora de Gracia & 1 & 1,49 \\
\hline Nuestra Señora del Carmen & 1 & 1,49 \\
\hline Remedios & 1 & 1,49 \\
\hline Copacabana & 1 & 1,49 \\
\hline Guadalupe & 1 & 1,49 \\
\hline Piedad & 1 & 1,49 \\
\hline Humildad y Paciencia de Cristo & 1 & 1,49 \\
\hline San José & 1 & 1,49 \\
\hline San Eloy & 1 & 1,49 \\
\hline Santa Catalina de Sena & 1 & 1,49 \\
\hline Santa Bárbara & 1 & 1,49 \\
\hline San Roque & 1 & 1,49 \\
\hline Ángel & 1 & 1,49 \\
\hline TOTAL & 67 & 100 \\
\hline
\end{tabular}


Como se anotó líneas arriba, fueron los mercaderes los que integraron el grupo mayoritario de los portugueses cofrades seguidos muy de cerca por los productores artesanales. Los primeros, en su mayoría medianos comerciantes, optaron preferentemente por la cofradía de Ánimas, establecida en las iglesias parroquiales Mayor, Santa Ana y San Sebastián, y por la de Nuestra Señora del Rosario, en el convento de Santo Domingo. ¿Esta elección sugiere razones puramente espirituales o más bien sociales y de apoyo por parte de los hermanos cofrades?

Resulta interesante saber que las cofradías de Ánimas, vinculadas especialmente a las iglesias parroquiales, fueron de las «más extendidas», por cuanto recogían en sus estatutos «de forma muy destacada el tema funerario y de sufragios por los miembros que fallecían», lo que de alguna manera nos da luces sobre la «creencia en la vida eterna, en el purgatorio [y] en la retribución» ${ }^{21}$ De los cinco comerciantes lusos integrados en la cofradía de Ánimas limeña, solo dos la escogieron de forma exclusiva; los otros tres la eligieron a la par con otro tipo de asociaciones, que tenían en común el garantizar el apoyo espiritual y la oración por el alma de sus miembros difuntos. El mercader Francisco Barroso, natural de la Vila do Conde y residente en el puerto de El Callao, dictó testamento en 1627 porque se hallaba enfermo del cuerpo. En él detallaba, de forma bastante extensa, los asuntos terrenales relacionados con sus negocios y con las deudas a favor y en contra; pero reservaba también otro espacio para los asuntos de su conciencia. Perdonaba a sus enemigos y demandaba, al mismo tiempo, el perdón a todas las personas «a quienes deba alguna cosa», remitía esta reflexión acaso a su hija natural Francisca, a quien reconoció, crio y alimentó como el padre que era, pero con quien tuvo ciertas desavenencias a causa de «la falta de honradez y desobediencia» de la susodicha.

En las cláusulas relativas al rito funerario, Francisco Barroso concedió un papel protagónico a las cofradías de las que era hermano. Como buen portugués se había integrado en la de San Antonio y, como tal, se mandó enterrar «en la capilla del señor San Antonio de Padua donde soy veinticuatro». Era también veinticuatro de otras tres cofradías, en este orden: «de la del Rosario, y la Madre de Dios del Buen Viaje y [de] la de las Ánimas», estas debían acudir, junto con la de San Antonio, con su cera, el día del funeral. Barroso en su testamento encargaba a sus albaceas que las misas de sufragio se dijeran especialmente en la capilla de Ánimas de la catedral

21 Campos, 2014, 21-22 y 34. 
del puerto. ${ }^{22}$ Este portugués era comerciante de trigo y propietario de dos navíos, su integración en las cuatro cofradías mencionadas no respondía ni a criterios nacionales ni a intereses económicos. En realidad, los comerciantes portugueses de Lima — los de mediano caudal - no contaron con hermandades nacionales que agruparan a este sector, mucho menos con otro tipo de asociaciones que defendiera sus intereses comerciales de forma colegiada. ${ }^{23}$ Se integraron en cofradías de carácter más bien abierto y local.

Otro grupo de los portugueses cofrades fueron productores artesanales, lo que revela la relación que hubo entre las cofradías y algunos gremios. En este sentido, y de acuerdo con la documentación revisada, se mencionan hasta tres cofradías con criterio gremial, que habrían agrupado a los productores lusos: San Lorenzo, asociada al gremio de los herreros; San Eloy, al de los plateros; y San José, vinculada al gremio de los carpinteros. Otras asociaciones elegidas fueron: la congregación de Nuestra Señora de la O, fundada en el colegio de San Pablo de la Compañía, y las cofradías de la Soledad, Santa Catalina de Sena, Ánimas y San Roque.

La presencia en Lima de determinados gremios de profesionales y de productores revela el crecimiento de la ciudad, lo que trajo como consecuencia inherente una demanda de productos manufacturados que iban desde vestidos, zapatos, tintes hasta obras de carpintería, hechuras de armas, trabajos en metales preciosos, entre otros. Este requerimiento no se solventó únicamente con la importación de tales géneros, sino que ya en el siglo XVII buena parte de la producción artesanal o manufacturera se realizaba en tiendas y talleres instalados en suelo limeño. ${ }^{24}$

En el caso de los productores extranjeros, y en particular de los portugueses, es probable que algunos hubiesen llegado a Lima con un oficio aprendido en la tierra de origen. Es probable también que otros hubiesen adquirido la destreza y la certificación en determinada habilidad en la propia Ciudad de los Reyes. ${ }^{25}$

22 Bienes de difuntos: Francisco Barroso, Traslado de testamento, Puerto de El Callao, 20-V1627, AGI, Contratación, 384, n. 3, r. 10 (1635-1636), 74r-98r.

23 En Sevilla, en cambio, la hermandad de San Antonio, más que una asociación nacional, había representado «un buen instrumento en manos del colectivo de hombres de negocios portugueses radicados en la ciudad, ya que esta hermandad facilitaba un provechoso espacio de sociabilidad entre comerciantes, en el que establecieron sus alianzas y acuerdos comerciales». Pulido Serrano, 2006, 39.

24 Quiroz, 2008.

25 Véase el caso de Pascual de Silva. Asiento de aprendiz del portugués Pascual de Silva con el maestro Pedro de Noguera, en el oficio de ensamblador y entallador, Lima, 11 de febrero de 1621, AGN, Prot. Not. 833, Francisco Hernández (1621), 236r-237v. 
De acuerdo con la documentación consultada, los artesanos lusos de Lima no fueron grandes productores, o si se quiere hombres de grandes recursos, tal como lo explica Quiroz ${ }^{26}$ sino más bien artesanos o pequeños productores directos, que trabajaban de forma independiente en sus propias casas o talleres, que atendían la demanda de particulares, y que en ocasiones contaron con el auxilio de asistentes para la atención de los pedidos. De los veinte artesanos lusos que se hallaron en Lima de 1570 a $1680,{ }^{27}$ nueve de ellos se integraron en alguna cofradía, más motivados por un vínculo espiritual. Solo cuatro lo habían hecho en cofradías asociadas al gremio de su oficio, llamados más por establecer un vínculo económico y espiritual. Estos últimos cuatro agremiados fueron Sebastián Jorge y Domingo Gaspar Herrera, oficiales herreros y cerrajeros que pertenecieron a la cofradía de San Lorenzo; Lázaro Nieto, de oficio platero, que se integró en la cofradía de San Eloy, y, por último, Francisco Lorenzo, maestro carpintero, que ingresó en la cofradía de San José. ${ }^{28}$

Esta vinculación de los portugueses con las cofradías de sus gremios revela una capacidad de integración tanto en la ciudad como al interior de la corporación. Esto da cuenta de que, a pesar de su situación jurídica de extranjeros, los oficiales y maestros portugueses no enfrentaron problemas de exclusión en el ejercicio de su actividad profesional. Al contrario, no serían pocos los que vivieron de su oficio ni raros los casos de productores extranjeros que habrían gozado de la confianza y estima de los ciudadanos limeños. ${ }^{29}$ Por otro lado, hubo entre estos extranjeros los que probablemente fueron más lejos aun y buscaron establecerse de forma definitiva en la ciudad. Tal fue el caso de Francisco Lorenzo, maestro carpintero, quien decidió instalar taller propio y quedarse en la ciudad por un tiempo prolongado,

26 Quiroz, 2008, 16-17.

27 Sullón Barreto, 2016, 116.

28 Conviene anotar que no necesariamente los que se definían a sí mismos como productores estaban integrados en un gremio, ni tampoco habían pasado por las etapas de aprendizaje, oficialazgo y maestría; es probable que la mayoría se hubiere desempeñado como «oficiales no agremiados» por la sencilla razón de que no existían, en el interior de estas corporaciones, mecanismos reales de coerción, es decir, que los gremios no podían obligar a pertenecer a su institución a los que practicaban por cuenta propia su oficio. Así pues, hemos encontrado en la documentación casos de productores que se denominaban a sí mismos cordoneros, carpinteros o plateros, señalando, de manera indistinta, que eran oficiales o maestros; otros, que pertenecían a un gremio, o a un gremio y a una cofradía gremial a la vez, o solo a la cofradía; e incluso hubo los que se habían integrado en una cofradía no gremial. Agradezco al doctor Francisco Quiroz Chueca por haber respondido generosamente a mis consultas y por haberme ayudado a aclarar este asunto. Para un estudio de los gremios en la Lima del tiempo que nos ocupa, véase Quiroz, 1995.

29 Moreno Cebrián y Sullón Barreto, 2014, 12. 
en compañía de su mujer y de sus seis hijos legítimos. Esto representó en la práctica una prueba evidente de su asentamiento definitivo en Lima.

Francisco Lorenzo era natural «de la villa de Castro Marim en los Algarbes, en la raya de Castilla y Portugal», y había llegado al Perú, probablemente, en los primeros años del siglo XVII. ${ }^{30}$ En 1609 la documentación lo sitúa ya en Lima donde realiza algunas transacciones económicas, entre otras, se dedica a la compra y venta de esclavos traídos desde Tierra Firme. ${ }^{31}$ Se casó, no hay certeza si en el Perú, con Elvira Rodríguez, natural del ducado de Osuna, con quien tuvo seis hijos: Salvador Lorenzo, Juan Lorenzo, José Lorenzo, Clemente Lorenzo, María de los Ángeles y Juana Rodríguez. Al momento en que testó, en 1633, el mayor de los hijos bordeaba los 25 años y la última hija «anda en edad de trece años», según sus propias palabras.

Esta situación de padre de familia numerosa lo inclinó acaso a fijar su residencia definitiva en Lima. Y fue en la capital donde labró «unas casas altas y bajas con tres puertas a la calle», en la calle que va «de los Plateros a la iglesia de la Compañía de Jesús»; y donde compró «otras dos casas bajas pequeñas [...] que lindan con las de suso declaradas». Como se mencionó líneas arriba, más allá de sus labores de maestro carpintero, Lima también fue el centro de sus operaciones comerciales, desde donde establecería contactos con Tierra Firme para la provisión de ciertos géneros de mercadería, entre ellos el comercio de esclavos. Este negocio le permitió crear vínculos con otros portugueses que se hallaban del mismo modo radicando en tierras peruanas, entre otros, el capitán Manuel Lopes y los mercaderes Luis Gomes Barreto y Manuel Baptista Peres. Estos dos últimos le habían suministrado, en 1621, algunos esclavos, que Lorenzo distribuyó en el mercado interno. ${ }^{32}$ Lo más probable es que sus mayores ingresos procedieran justamente de esta actividad mercantil y nuestro portugués destinara parte de su capital al desarrollo de la actividad productiva, la carpintería.

30 Testamento de Francisco Lorenzo, Lima, 16 de setiembre de 1633, AGN, Prot. Not. 780, Francisco Gonzáles de Balcázar (1632-1633), 357r-364v.

31 Escritura de venta de un esclavo, Francisco Lorenzo a Gerónimo Justo de Porras, Lima, 11 de abril de 1609, AGN, Prot. Not. 2020, Joan Zamudio (1609), 300r-302r. Escritura de venta de una negra esclava, Francisco Lorenzo a Beatriz López de Sanabria, Lima, 26 de junio de 1609, AGN, Prot. Not. 2020, Joan de Zamudio (1609), 489v-492r. Escritura de venta de una negra esclava, Francisco Lorenzo a María Gonzáles, Lima, 29 de mayo de 1609, AGN, Prot. Not. 2020, Joan Zamudio (1609), 513r-514v.

32 Para estos contactos, véase: Carta poder para testar del capitán Manuel Lopes a Leonor de Melo, su mujer, Lima, 1. ${ }^{\circ}$ de enero de 1616, AGN, Prot. Not. 1735, Diego Sánchez Vadillo (1616), 2210v. Escritura de venta de un negro esclavo, el capitán Manuel Baptista Peres a Francisco Lorenzo, Lima, 2 de agosto de 1621, AGN, Prot. Not. 1209, Diego Nieto Maldonado (1621), 1923v-1925r. 
Así, más tarde Lorenzo se encontraría en condiciones de instalar en una de sus casas un taller de carpintería, que aderezó con muebles para tal efecto y «herramientas de mi oficio de carpintero», los cuales fueron avaluados, en el momento de testar, en unos 400 pesos de a ocho reales. Contó para el cumplimiento de su oficio con el auxilio de tres esclavos: dos oficiales carpinteros, y un oficial tornero, lo cual sugiere la práctica efectiva del oficio por parte de este portugués. Sin duda la carpintería le obligaría a permanecer la mayor parte del tiempo en la ciudad, en tanto para sus negocios con Tierra Firme contó con el intermediario Diego Martín, yeguarizo, quien en 1633 había llevado del susodicho «seis mil pesos de a ocho reales $[\ldots]$ a emplear por mi cuenta al reino de Tierra Firme». ${ }^{33}$

Es evidente que razones económicas habrían justificado la decisión de Lorenzo de arraigarse en la ciudad, pero no sería la única. Francisco Lorenzo se había casado con una natural del reino, probablemente para afianzar su relación con la tierra nueva. Vínculo que se hizo más firme con los numerosos hijos que tuvo con ella, lo que lo indujo a levantar varias casas que le sirvieran de morada tanto para él como para su familia; se suma a ello un genuino interés de integrarse hasta en tres cofradías de la ciudad. ${ }^{34}$ Todo esto nos remite a ese sentido de pertenencia e identidad con la tierra de adopción.

En este contexto su vínculo con las cofradías, especialmente con la de San José, supuso para este portugués no solo una forma de garantizarse el auxilio espiritual para su alma y la perpetuación del nombre, sino también un medio por el que dejaba asegurado, «para siempre jamás», el sustento y la manutención de algunos de sus descendientes. En 1633, Francisco Lorenzo fundó una capellanía de misas en la capilla de San José de la iglesia Mayor, con una renta de 300 pesos cada año; el nombramiento de patrón y capellán recayó en uno de sus hijos, Juan Lorenzo, clérigo secular, quien debía gozar de 200 pesos de esa renta, deducidos diez pesos para la ofrenda. Los cien restantes quedarían aplicados en otro de sus vástagos, su hija María de los Ángeles, monja novicia del convento de Santa Clara, «para sus necesidades y vestuario»..$^{35}$

33 Testamento de Francisco Lorenzo, Lima, 16 de setiembre de 1633, AGN, Prot. Not. 780, Francisco Gonzáles de Balcázar (1632-1633), 357r-364v.

34 En 1633 era hermano de las cofradías siguientes: San José, Nuestra Señora de la O, y San Lorenzo.

35 Testamento de Francisco Lorenzo, Lima, 16 de setiembre de 1633, AGN, Prot. Not. 780, Francisco Gonzáles de Balcázar (1632-1633), 360. 
En el caso de los marineros y soldados, si bien su integración en las cofradías de Lima y de El Callao obedeció más bien a un criterio espiritual o de identificación con ciertas devociones particulares — caso de San Antonio, Rosario, Soledad, o Santo Cristo- por lo general los navegantes y soldados portugueses optaron por aquellas corporaciones que eran afines a su actividad profesional. Los marineros, por un lado, no solo habrían dispuesto de dos hospitales para su atención, el de Nuestra Señora de Covadonga y el del Espíritu Santo, sino también de una cofradía propia, como la de Nuestra Señora del Buen Viaje, fundada en el convento de San Agustín del puerto de El Callao, que agrupaba al gremio de los calafates. ${ }^{36}$

Los soldados, por su parte, incluidos dentro del «personal de la Armada», si bien debieron compartir y costear junto a los marineros «los gastos de hospital [...] y la cofradía de la gente de mar», ${ }^{37}$ se hallaban integrados en la cofradía de la Limpia Concepción, fundada en el convento de San Francisco del puerto de El Callao. Es probable, para el caso de los hombres de la milicia, que su integración en esta cofradía tuviese carácter forzoso, como lo hace notar Francisco Gonçales, soldado de la compañía del almirante Pedro Alfonso y Muñoz. En su testamento, dictado el 10 de octubre de 1625, este personaje dispone su entierro en la iglesia de San Francisco de dicho puerto, en los siguientes términos: «en la parte donde todos los soldados tenemos nuestro entierro por estar fundada allí la cofradía de Nuestra Señora de la Limpia Concepción, a cuyo cargo del mayordomo de la dicha cofradía está el pagar el dicho entierro». ${ }^{38}$ Seguramente la cuota para el sostenimiento de la citada cofradía era descontada de la paga mensual de estos soldados, de manera forzosa. A cambio, disfrutaban de los beneficios espirituales señalados para tal efecto.

No en todos los casos los soldados portugueses se hallaban integrando, de forma obligatoria, la cofradía de la Concepción. Hubo algunos que eligieron otras corporaciones de diferente advocación, lo cual revela ese margen de libertad manifestado en la expresión de la última voluntad y trasluce, de alguna manera, un genuino afecto que los hombres de Portugal habrían sentido por determinadas devociones. Manuel Rodrigues, natural de Barcelos, era soldado de la compañía del capitán don Pedro de Corcuera, del presidio de El Callao, y como tal se hallaba afiliado a la cofradía de

36 Campos, 2014, 124.

37 Pérez-Mallaína y Torres, 1987, 69-70.

38 Testamento de Francisco Gonçales, Puerto de El Callao, 10 de octubre de 1625, AGN, Prot. Not. 1811, Marcos de Santisteban (1625), 876v. 
los soldados del convento de San Francisco. No obstante, en 1633 declaró que era también hermano veinticuatro de las cofradías de San Antonio y de Nuestra Señora del Buen Viaje. Su lugar de sepultura lo señaló en la capilla del santo lisboeta, pero encargaba a sus albaceas que, una vez que ocurriera su muerte, dieran pronto aviso al mayordomo «de la cofradía de los soldados» para que acudan a «hacer el dicho entierro, según y como [a] los tales soldados se acostumbra». ${ }^{39}$

Lo expuesto hasta aquí sugiere que no hubo determinadas corporaciones o asociaciones de carácter nacional que integraran a todos los portugueses de Lima. La clasificación de los lusos por su actividad económica o profesional pone de manifiesto que, en el plano espiritual, estos habían elegido cofradías de variada advocación, inducidos por devociones queridas y no solo porque se hallaban vinculadas al gremio de su profesión. Por otro lado, en el caso de los productores, los marineros y los soldados, si bien pudo existir un sentido de corporación al interior de cada gremio, no fue determinante para limitar una relación exclusiva con gente de la misma nación, pues se sabe que estas corporaciones integraron a españoles y también a otros extranjeros, inclusive a «zambos y mulatos», ${ }^{40}$ lo que evidencia no solo el sentido de apertura de la sociedad de ese tiempo, sino también el carácter exogámico de los vínculos sociales de los lusos.

\section{Otras vías de integración a través de las cofradías}

Aparte de los portugueses cofrades encontramos en la documentación los casos de otros lusos que no pertenecieron de manera definitiva a cofradía alguna, pero sí se hallaban vinculados a estas asociaciones, ya sea por la vía de limosnas, por el alquiler de casas pertenecientes a determinadas cofradías o a través del matrimonio con doncellas huérfanas, que se hallaban criando en las casas de recogimiento regidas por estas corporaciones. Lo más común fueron las mandas de limosnas con cargo al acompañamiento del cuerpo el día del funeral.

Las disposiciones testamentarias del rito funerario contemplaban, básicamente, la elección del lugar de sepultura, el tipo de mortaja a llevar y el acompañamiento del cuerpo. Algo más del $96 \%$ de los casos conocidos

39 Bienes de difuntos: Manuel Rodrigues, Traslado de testamento, Puerto de El Callao, 21 de julio de 1633, AGI, Contratación, 421B, n. 5 (1648), 23r-40r.

40 Pérez-Mallaína y Torres, 1987, 68-69. 
indicó claramente dónde querían ser sepultados. El hábito de San Francisco fue el preferido como mortaja por la gran mayoría.

Para el caso que se estudia fueron 40 los portugueses que, aun sin ser cofrades, pidieron la presencia de determinadas cofradías y hermandades como acompañamientos al funeral. No era una deferencia a la que las corporaciones accedían de manera gratuita, a cambio de esta acción, percibían una retribución, en la figura de limosnas que el difunto dejaba señaladas en el testamento. De las cofradías citadas para este efecto destacaron especialmente la de Ánimas y la Hermandad de los Niños Huérfanos, seguidas por Redención de Cautivos, Rosario, Soledad y Santísimo Sacramento de la catedral. Estas cofradías remiten a ese deseo de salvación del alma a través de la oración, de todo ese cuerpo organizado, pero también por medio de la expiación.

Las limosnas fueron por lo general de diez, veinte o cincuenta pesos, otros asignaban montos menores de dos, cuatro o siete pesos, mientras que las más altas donaciones variaron de doscientos a quinientos pesos. Una de estas últimas procedió del licenciado Manuel Correa, clérigo secular y rico mercader, quien dictó testamento el 11 de abril de 1623; y entre sus numerosas donaciones - destinadas a casas de recogimiento, colegios, conventos y hospitales - destacan algunas que estuvieron orientadas a cofradías y hermandades. Mandó quinientos pesos para la hermandad de Redención de Cautivos, doscientos pesos para «la cofradía de la Visitación de Santa Isabel» y otros doscientos pesos «para la cofradía del Santo Nombre de Jesús». ${ }^{41}$ Estas limosnas destinadas a estas corporaciones limeñas se cuentan entre las más altas de los casos analizados. Por lo general las limosnas se fijaban en pesos y patacones, sin embargo, algunos portugueses las señalaron en especie, tal fue el caso de Benito Baña Cardoso, quien en 1625 mandó a la cofradía de San Nicolás de Tolentino de la iglesia de San Agustín «cuatro libras de cera para que ardan en su altar», pedía a cambio «una misa rezada al dicho santo por mi ánima». ${ }^{42}$

Otros portugueses se mandaron enterrar en las capillas donde se habían fundado determinadas cofradías (Rosario, San Antonio, Ánimas, Santo Cristo, San Eloy, Redención de Cautivos). Se entiende, entonces, que tal derecho no estuvo solo reservado a los hermanos veinticuatro o al resto

41 Testamento de Manuel Correa, Lima, 11 de abril de 1623, AGN, Prot. Not. 1740, Diego Sánchez Vadillo (1619-1623), 703r-728r.

42 Testamento de Benito Baña Cardoso, Lima, 11 de marzo de 1625, AGN, Prot. Not. 1852, Antonio de Tamayo (1625-1626), 122r-126v. 
de sus miembros, sino también a todo aquel que así lo deseaba, siempre y cuando pudiese pagar por los derechos de tal sepultura. En 1629 Antonio Dias, natural de las islas Terceras, se mandó enterrar en la capilla de las ánimas de la iglesia de Santa Ana. El costo por este enterramiento fue de cuarenta pesos de a ocho reales que, en realidad, fue el precio que pagó José de Espinoza, albacea del susodicho, al mayordomo de la cofradía. Además tuvo que pagar otros diez pesos más «por el acompañamiento que hizo al cuerpo del dicho difunto la insignia y cera de la dicha cofradía». ${ }^{43}$ Por otro lado, hubo dos portugueses cuyos vínculos con las cofradías y hermandades no se dieron precisamente en el plano espiritual, sino más bien en el económico: ambos vivían de alquiler en casas que pertenecían a estas corporaciones religiosas.

Consta en la documentación que tanto la hermandad de la Caridad como la cofradía de la Limpia Concepción dieron en arrendamiento casas de su propiedad a individuos de naturaleza portuguesa. La primera había concertado un contrato de alquiler — de casa y pulpería «por [de]bajo de San Sebastián»—- con José Rodrigues, quien para julio de 1622 adeudaba a la dicha hermandad «veinte y ocho pesos de a ocho reales por un tercio de cuatro meses corridos de la casa y pulpería que el [susodicho] tenía arrendadas» ${ }^{44}$ La segunda tuvo trato con el maestro sastre Andrés Muñiz. Sobre este segundo caso se conocen mejor las condiciones del arrendamiento, y también existen mayores detalles del portugués en cuestión.

Andrés Muñiz era maestro sastre, natural de las islas Terceras, y llegó al Perú probablemente a comienzos del siglo XVII, según consta en un contrato de venta de una esclava que suscribió con Martín Gil Real el 8 de noviembre de $1624^{45}$ y que lo sitúa en Lima por ese tiempo. Desde ese año hasta 1648 en que hizo testamento, su nombre aparecerá en numerosas escrituras lo que evidencia el dinamismo social y económico del personaje. Muñiz practicó el comercio a mediana escala, dio en alquiler a algunos de sus esclavos, realizó préstamos de capital, ejerció de maestro de aprendices en el oficio de sastre, y dispuso de un taller en la calle de los Mercaderes donde atendió numerosos encargos de «hechuras de vestidos». No obstante esa capacidad multifacética, se trató de un poblador con residencia fija en

43 Testamento de Antonio Dias, Lima, 24 de diciembre de 1629, AGN, Prot. Not. 1853, Antonio de Tamayo (1630), 611r-648v.

44 Traslado de carta poder para testar de José Rodrigues a Francisco López de Palma, Lima 3 de julio de 1622, AGI, Contratación, 539A, n. 12, Autos de bienes de difuntos (1635).

45 Escritura de venta de esclava de Andrés Muñiz a Martin Gil Real, Lima, 8 de noviembre de 1624, AGN, Prot. Not. 1758, Diego Sánchez Vadillo (1624), 2163r-2164r. 
la Ciudad de los Reyes. Curiosamente, no contrajo matrimonio ni declaró hijos naturales en el Perú. Lo que sí reconoció, por una declaración de 1636, es que «fue casado con María de Francia, en la ciudad de Puerto de Portugal, que por divorcio de lo eclesiástico y pleito en lo criminal [...] se apartaron para siempre». ${ }^{46}$

En Lima, el portugués Muñiz asumió el cuidado y la atención de una doncella, «doña Ana María de Mendoza, huérfana de padre y madre», cuyos vínculos con el maestro sastre no se precisan en la documentación. El texto menciona que en 1632 firmó una escritura de obligación con el licenciado Pedro de Guzmán, mayordomo del monasterio de la Concepción, para que recibiera a la susodicha como monja de velo negro. El luso se comprometía a entregar al momento de la firma de la escritura «cien pesos de a nueve reales por la colación y propinas de la entrada de la dicha doña Ana María de Mendoza con más de tres arrobas y media de cera labrada de la dicha entrada y más cincuenta pesos ensayados de los alimentos de los primeros seis meses de la susodicha». Aparte de ello, entregaría en el momento de su profesión 3.195 pesos de a ocho reales en calidad de dote. ${ }^{47}$ Es probable que algún vínculo afectivo uniera a estas dos personas, sin el cual no se entendería la generosidad del portugués. También le había hecho donación de «una negrita», «desde que nació y acabada de destetar», y, una vez que entró al convento, se la envió «como cosa propia suya» para que esté en su compañía ${ }^{48}$ Cuatro años después Muñiz seguiría en contacto con doña Ana María de Mendoza, esta vez «monja profesa en el monasterio de la Limpia Concepción», a quien mandó entregar — por razón de que «es pobre»— 18 varas de ruan y un pedazo de bramante. ${ }^{49}$

Uno de los aspectos interesantes en la biografía de Andrés Muñiz, aparte del ejercicio efectivo de su profesión, fue el vínculo afectivo que estableció con la Orden de San Francisco: capillas, hermanos religiosos y cofradías. Es probable que hubiese servido en la capilla de Nuestra Señora del Milagro, a la que hizo donación, según su testamento, de cierta cantidad de pesos, de un frontal de plata y del servicio «por todos los días de su vida» de uno de sus esclavos. Mandó además «que todo lo que está sirviendo a

46 Prisión y secuestro de bienes de Andrés Muñiz, Lima, 23 de mayo de 1636, AGN, SO-CO $64-457,5 \mathrm{v}$

47 Escritura de obligación de Andrés Muñiz al monasterio de la Concepción, Lima, 6 de diciembre de 1632, AGN, Prot. Not. 1778, Diego Sánchez Vadillo (1632), 2542r-2543v.

48 Prisión y secuestro de bienes de Andrés Muñiz, Lima, 23 de mayo de 1636, AGN, SO-CO 64-457, 178r.

49 Ibidem, 2 r. 
la dicha capilla que fuere mío se quede a su servicio y no se venda aunque constare ser bienes míos». Será en esta capilla donde el portugués fijaría su lugar de sepultura. En 1648 el maestro sastre declaró que era hermano profeso de la Tercera Orden de San Francisco. Seguramente esta situación le llevó a establecer vínculos de afecto con los hermanos del convento, entre ellos con fray Diego Vadillo, sacristán mayor, a quien nombrará por uno de sus albaceas y le confiaría, asimismo, la memoria de sus deudas por cobrar y la fundación de una capellanía.

La cercanía con la cofradía de la Limpia Concepción se manifestó de tres formas distintas. La primera, en el nombramiento de albaceas, pues junto a fray Diego Vadillo fueron llamados «los mayordomos que son o fueran de la cofradía de la Limpia Concepción». Esto sugiere que debió existir una relación de confianza con los miembros de esta cofradía, por cuanto la tarea de recoger los bienes, cobrar las deudas y cumplir las últimas voluntades señaladas en las mandas, solo se encomendaba a personas de confianza.

La segunda forma revela la intención del portugués de querer beneficiar a la cofradía de la Concepción en las mandas de limosnas. En el momento de testar, Andrés Muñiz nombró por heredera su alma y encargó a fray Diego Vadillo la institución, en la capilla de Nuestra Señora del Milagro, de una capellanía de misas. Fue justamente esta capilla la que recibió los mayores beneficios de los bienes y las rentas legados por el portugués, el $50 \%$ de todos ellos, por su parte la cofradía de la Concepción percibiría el $25 \%$ de los mismos, además de «cierta cantidad [de pesos] para ayudar a casar huérfanas de la [dicha] cofradía». ${ }^{50}$

La devoción o el cariño por esta cofradía es probable que hubiese surgido en correspondencia con la práctica de su oficio. Muñiz como maestro examinado seguramente había formado parte del gremio de los sastres, que de acuerdo con sus constituciones había quedado asociado a la cofradía de la Concepción.

La tercera forma está referida a un contrato de alquiler de casas que el mayordomo mayor de la cofradía de la Concepción de la catedral efectuó con el sastre Andrés Muñiz. Las casas en cuestión estaban situadas en la calle de los Mercaderes, y fueron arrendadas al portugués por tiempo de dos años, «que han de comenzar a correr y a contarse desde el primero de enero [...] de 1625», siendo el precio pactado de 656 pesos de a ocho reales por cada año. El arrendamiento seguramente se prolongó por algún tiempo más,

50 Testamento de Andrés Muñiz, Lima, 23 de julio de 1648, AGN, Prot. Not. 1025, Miguel López Varela (1648), 1584r-1588r. 
pues en 1636 el sastre luso reconocía todavía una deuda por pagar a Jácome de Quezada, mayordomo de la cofradía, «de dos tercios de la casa en que [vive] este declarante, a razón de a 516 pesos al año». ${ }^{51}$

Andrés Muñiz, aunque no invirtió en la compra de bienes raíces, sí se aseguró de un arrendamiento por largo tiempo, pues la documentación revela que, al menos para los años de 1625 a 1636, viviría en casas pertenecientes a la cofradía de la Concepción, en una de las calles principales y de mayor movimiento comercial de Lima. Sus vínculos con esta cofradía eran por demás evidentes. Su entrada como hermano de la tercera orden ayudaría a estrechar su relación con el convento grande de San Francisco, lo cual se puso de manifiesto a través de la distribución total de su herencia a este mismo convento, aunque repartida entre «la capilla de Nuestra Señora del Milagro para su festividad [...], las misas de sufragio de a peso por los religiosos del dicho convento, y la otra para ayuda de la cofradía». ${ }^{52}$ Entre sus bienes se contaron imágenes de los santos Antonio y Francisco y dos cuadros con el rostro de Nuestra Señora de la Concepción, como colofón a su cercanía con esta advocación..$^{53}$ Finalmente, resta por citar otra vía de acercamiento entre las cofradías y los portugueses no cofrades.

Algunas de las cofradías y hermandades limeñas regentaron casas de recogimiento de huérfanas, es el caso de la hermandad de la Caridad, de la Concepción, o del Rosario. Particularmente interesa citar la hermandad de la Caridad que, de acuerdo con la descripción que presenta Cobo, entre las numerosas obras pías que ponía en marcha esta institución estaba también la de:

recoger doncellas mestizas que sirviesen a las enfermas, y a título de sirvientas las casaban y dotaban [...] y como después fuesen creciendo las limosnas dieron en recoger algunas doncellas españolas pobres [...] las cuales criaban dentro del hospital, y cuando eran de edad las casaban como a las primeras y daban a cada una cuatrocientos pesos de dote. ${ }^{54}$

Una de estas doncellas españolas que se hallaba en el recogimiento de la Caridad fue María Flores Bravo, natural de la villa de Las Brozas, e «hija legítima de Juan Cantero, difunto, y de Ana Flores Bravo, que al presente

51 Prisión y secuestro de bienes de Andrés Muñiz, Lima, 23 de mayo de 1636, AGN, SO-CO $64-457,3 \mathrm{v}$.

52 Testamento de Andrés Muñiz, Lima, 23 de julio de 1648, AGN, Prot. Not. 1025, Miguel López Varela (1648), 1584r-1588r.

53 Prisión y secuestro de bienes de Andrés Muñiz, Lima, 23 de mayo de 1636, AGN, SO-CO 64-457, 6r.

54 Cobo, 1882, 313-314. 
es mujer de Gonzalo Gómez». ${ }^{55}$ Esta doncella española casará en Lima con el portugués Gaspar Rodrigues Montero. Es probable que el concierto para dicho matrimonio haya sido tratado entre el portugués y los tutores de la susodicha. Lo cierto es que en 1614 Rodrigues Montero reconoció haber recibido en dote y casamiento la limosna de la dicha casa de la Caridad, «que son cuatrocientos pesos de a nueve rreales», más otros cien pesos que le mandó su padrino «al tiempo y cuando la susodicha salió en la procesión que se suele y acostumbra hacer de las doncellas que sacan de la dicha casa de la Caridad», ${ }^{56}$ y asimismo «quinientos ochenta y un pesos de a ocho reales en bienes muebles de ajuar de casa y vestidos»; en total el monto de la dote habría sumado 1.143 pesos y cuatro reales de a ocho. Por su parte, la hacienda del portugués se estimó en unos veinte mil pesos distribuidos en plata labrada, joyas, ropa blanca, vestidos de su mujer, trastes de casa, dos mulas ensilladas y enfrenadas, esclavos y varias botijas de vino. Se entiende que la hacienda del portugués, aunque no puede considerarse como una «gran hacienda» para el contexto de la época, tampoco era escasa. El matrimonio con esta doncella española habría supuesto para Rodrigues Montero una estrategia de integración, toda vez que los extranjeros, especialmente los portugueses, fueron objeto de vigilancia por aquella época de las primeras décadas del siglo XVII, bajo sospecha de judaísmo.

El matrimonio con una natural del reino habría garantizado, de cara a las autoridades, la intención de este extranjero de querer avecindarse en la ciudad, pero también era una demostración externa de su fe cristiana, por cuanto el susodicho había decidido casar y velar según orden de la santa madre Iglesia de Roma.

\section{San Antonio de Padua en la mentalidad de los lusos limeños}

En este epígrafe se abordará el tema de la memoria y de la identidad o identidades de los portugueses que se hallaron en Lima. Frente a este grupo extranjero se hallan dos referentes identitarios. Por un lado, la patria de origen. Y por otro, la tierra de adopción. De acuerdo con los testamentos revisados, los portugueses, en su mayoría, conservaron el recuerdo de sus progenitores (aunque esto no se tradujo necesariamente en la existencia de

55 Dote de Gaspar Rodrigues Montero a María Flores Bravo, Lima, 25 de mayo de 1614, AGN, Prot. Not. 823, Francisco Hernández (1614), 1338r-1344v.

56 Sobre la procesión de las dichas doncellas, véase Cobo, 1882, 313-314. 
comunicación entre ambos lados del océano); otros añadían a ese recuerdo el de ciertos paisanos y parientes (cónyuge, hermanos, hijos) a quienes procuran beneficiar en el testamento. Hubo también los que tuvieron muy presente a ciertas instituciones y lugares por donde habían transitado antes de emprender el viaje al Nuevo Mundo.

En efecto, los portugueses cofrades llevaron en su memoria hasta el día de su muerte el nombre de algunas instituciones, ermitas, capillas, hospitales, cofradías y pueblos de la tierra natal, que seguramente habían marcado o influenciado sus vidas o sus historias. Estos nombres aparecen recogidos en los respectivos testamentos, en las cláusulas referidas a donaciones y limosnas. Entre los más recordados se menciona la capilla de Nuestra Señora de la Buena Esperanza en la villa de Viana de Caminha; el hospital de la Misericordia de la misma villa; la capilla de Nuestra Señora del Rosario y la ermita de «señor Santiago» en la feligresía de San Martiño de Sande; las cofradías del Santísimo Sacramento y del Rosario de la iglesia de Santa María de Rivadançora; la cofradía de la Concepción en el convento de San Francisco de la ciudad de Oporto, y la cofradía de Nuestra Señora del Buen Viaje en la villa de Setúbal. Se cita, asimismo, la iglesia de la Compañía de Jesús de la ciudad de Sevilla como punto de referencia y de contacto con los herederos lusos. ${ }^{57}$ Nótese que las cofradías mencionadas - Santísimo Sacramento, Rosario, Concepción y Buen Viaje- se corresponden con sus homónimas fundadas en Lima, que asimismo habían atraído, en esta ciudad, a determinado número de portugueses, pero también a otros limeños, lo cual significa, para el caso que se analiza, que no hubo en la capital del virreinato peruano redes de cofradías o hermandades que agruparan solo a portugueses. En la manifestación de su fe y en el deseo de alcanzar la salvación del alma desde el mensaje católico, no existían diferencias entre estos y los españoles. ${ }^{58}$

Mención especial merece la figura de san Antonio de Padua en el ámbito limeño, y especialmente en su relación con el colectivo luso. El papel que habría cumplido la cofradía de San Antonio en la España Moderna

57 Poder para testar del capitán Manuel Lopes a Leonor de Melo, su mujer, Lima, $1^{\circ}$ de enero de 1616, AGN, Prot. Not. 1735, Diego Sánchez Vadillo (1616), 2207r-2211r. Testamento de Rodrigo García Carnero, Lima, 11 de diciembre de 1625, AGN, Prot. Not. 172, Agustín de Atencia (1623-1625), 1199r-1204r. Testamento de Sebastián Delgado, Lima, 29 de enero de 1626, AGN, Prot. Not. 836, Francisco Hernández (1626), 202r-207v.

58 Agradezco a Pilar Latasa por esta observación. Para un estudio sobre las cofradías como instrumento de la Contrarreforma en el Nuevo Mundo, véase Rodríguez Mateos, 1995. Para el caso portugués, Palomo, 2006, 92-104. 
como medio de unión de los portugueses radicados en territorio peninsular ha llevado a que nos preguntemos si esa misma cofradía tuvo el propósito de conservar o fortalecer los rasgos de identidad nacional de los portugueses que se hallaban viviendo en la Ciudad de los Reyes. De acuerdo con la documentación, encontramos que en veinticinco casos (de un total de 176) se hizo referencia a la figura del santo lisboeta. Algunos lo tuvieron en cuenta en la fundación de capellanías o al momento de señalar misas y limosnas. Otros porque se habían integrado como hermanos veinticuatro en cofradías fundadas bajo su advocación. Y hubo los que conservaron entre sus bienes lienzos, retablos e imágenes de talla de este santo franciscano. La mayoría se había mandado enterrar en capillas o bóvedas construidas en su honor. Estos datos revelan más bien que en la Lima del siglo XVII la figura de san Antonio de Padua se había erigido como una de las más populares en el medio, pero en ningún caso como elemento aglutinador de los inmigrantes lusos limeños.

La difusión del culto antoniano por todo el orbe americano fue obra de la Orden de San Francisco, que no solo buscó propagar la vida y milagros de su fundador, sino también la imagen de san Antonio «como ícono de cariz más popular de la orden religiosa que se afirmaba, dando cuerpo a la sencillez, a la humildad, a la sabiduría, a la sensatez, y a la ejemplaridad fundamentales». La orden franciscana puso bajo su advocación «hospitales, conventos y monasterios» ${ }^{59}$ y ya en Lima desde finales del siglo XVI, concretamente en 1588 , existía cofradía y capilla bajo su patrocinio.$^{60} \mathrm{De}$ otro lado, los símbolos franciscanos fueron los más populares en el colectivo analizado. La mayoría de los otorgantes lusos elegía como mortaja el hábito de san Francisco, mientras que entre las imágenes, lienzos y tallas de santos que estuvieron en su poder destacan especialmente Francisco y Antonio.

Aunque la figura de san Antonio de Padua no representó para los portugueses limeños un símbolo de identidad nacional (como se anotó antes, fue más bien una figura universal para los cristianos). Lo que sí se puede destacar es que, si bien de los casos conocidos solo el 14,20 \% hizo mención al santo lisboeta, siempre las referencias denotan proximidad y cariño y su elección se había efectuado o de forma exclusiva o con preferencia a otros santos o santas. En algunos pocos casos su invocación había precedido la

59 Santos, 2010, 2.

60 Bienes de difuntos: Rodrigo Paes, Traslado de testamento, Lima, 29 de julio de 1588, AGI, Contratación, 257B, n. 3, r. 1, 7r-12v. 
firma de ciertas escrituras notariales. ${ }^{61}$ En 1610 el bachiller Antonio Dias de Rivadeneira otorgó testamento «a honra y gloria de Nuestro Señor y de la Virgen Santa María», y agregaba también «al glorioso san Antonio de Padua, mi patrón y abogado». En 1623 el licenciado Manuel Correa mandó fundar una capellanía de «cuatro misas rezadas cada semana, y cuatro cantadas», estas últimas debían decirse en días especiales señaladas por su fundador, a saber: «el día de san Jacinto y la Ascensión y san Antonio de Padua y el día de la conmemoración de los difuntos o en su octava, perpetuamente para siempre jamás». Manuel Bautista, administrador del obraje de Cochán en la jurisdicción de Chancay, encargó en 1638 algunas misas de sufragio rezadas por la salvación de su alma, por las de los indios que le habían servido en dicho obraje y por las de sus familiares difuntos. Según dispuso, estas debían ser oficiadas en altares de ánimas de diversos conventos y dejó reservadas otras veinte «por mi intención en el altar de san Antonio de Padua del convento de San Francisco más cercano a la parte donde muriera», se entiende que solo estas últimas, las que estaban dirigidas a su intención particular, fueron señaladas en el altar del santo portugués. ${ }^{62} \mathrm{En}$ los tres casos se observa que la referencia a san Antonio de Lisboa obedeció más a cuestiones personales, de afecto o de cariño, que a criterios de índole nacional. ${ }^{63}$

¿Qué razones podrían explicar la ausencia de hermandades o cofradías que buscaran reunir a los inmigrantes portugueses de Lima? Sobre el particular se han planteado hasta tres hipótesis: la primera subraya el esfuerzo que habrían hecho los portugueses en la capital del virreinato «por

61 San Antonio, aunque figura universal, no dejaba de ser, en el contexto de la monarquía hispánica, una figura que había quedado asociada a todo lo portugués. Valga como apoyo a esta afirmación la hipótesis planteada por Pulido Serrano $(2015,46-53)$ acerca de las razones por las que Mateo Alemán habría compuesto su «Vida y milagros de san Antonio de Padua», señalando, entre otras, el interés comercial de dirigir esta obra «a un mercado preferentemente portugués». Algunos ejemplares de las ediciones de 1604 y 1605 fueron llevados a la América española, donde al parecer hubo alta demanda entre los castellanos y portugueses radicados allí; y es probable que para estos últimos la posesión de ese libro hubiera representado la memoria de la nación lusa. Agradezco al doctor Ignacio Pulido por haberme facilitado la referencia a esta publicación.

62 Testamento de Antonio Dias de Rivadeneira, Asiento de Boctalla del valle del Collao de Nasca, 10 de noviembre de 1610, AGN, Prot. Not. 181, Cristóbal de Barrientos (1604-1618), 701v-702r. Testamento de Manuel Correa, Lima, 11 de abril de 1623, AGN, Prot. Not. 1740, Diego Sánchez Vadillo (1619-1623), 712r. Testamento de Manuel Bautista, Lima, julio de 1638, AGN, Prot. Not. 1859, Antonio de Tamayo (1638), 919v-920v.

63 Esto mismo ocurrió en Tenerife, donde los portugueses radicados allí, si bien expresaron especial devoción a san Antonio, habrían venerado también «como cualquier otro tinerfeño a la Virgen de Candelaria», patrona de ese lugar, manifestando así cierta integración con el suelo local. Álvarez Santos, 2016, 396. Agradezco a Javier Álvarez por compartir esta información. 
no diferenciarse del resto de colonizadores y por el deseo de diluirse entre ellos»; la segunda apunta a la natural asimilación de los portugueses en el medio limeño, es decir, que no solo se integraron sino que se fueron «asimilando y mezclando con los nativos»; la tercera hipótesis toma en cuenta el número de los inmigrantes portugueses que había en Lima en la primera mitad del siglo XVII, es probable que fueran pocos para el conjunto de la población que no justificó la existencia o la fundación de algún tipo de asociaciones de coterráneos. ${ }^{64}$

Habría que añadir también que, aunque portugueses, se trató de un colectivo de cristianos o católicos, es decir, de bautizados, y desde ese punto de vista no había diferencias con sus pares españoles. Los medios que la Iglesia ponía al alcance de sus fieles para la salvación del alma tenían carácter universal, y san Antonio de Padua, aunque nacido en Lisboa, no fue la excepción. ${ }^{65}$

\section{A manera de conclusión}

Los datos analizados permiten deducir que no hubo en la Ciudad de los Reyes, en los años de 1571 a 1680, algún tipo de asociación cultural, económica o religiosa que agrupase solo a la gente de nación lusa. Desde el plano religioso, los portugueses, al igual que los otros limeños o españoles, pudieron acceder libremente a cualquiera de las cofradías o hermandades fundadas en el medio, independientemente de su lugar de procedencia.

Aunque los lusos limeños se habían integrado hasta en veinticinco cofradías o hermandades de la ciudad hubo preferencia por las de fundación franciscana, entre otras: Soledad, San Antonio, y Concepción, lo que evidencia el arraigo que había alcanzado la Orden de San Francisco en suelo americano. ${ }^{66}$ En este contexto, resulta evidente que la figura de San Antonio no se presentó como patrimonio exclusivo de los portugueses, sino como modelo universal de santidad propuesto por la Iglesia.

64 Pulido Serrano, 2006, 30-31.

65 Aparte, podríamos anotar que las autoridades de ese tiempo no fueron muy proclives a auspiciar asociaciones de extranjeros en la América hispana, especialmente agrupaciones de portugueses que, aun siendo vasallos del mismo rey, eran tenidos por sospechosos en materia de fe, y por rebeldes en el contexto de la Gran Complicidad y de la rebelión de Portugal en 1640. Agradezco este aporte a los evaluadores anónimos.

66 Otros habían profesado como hermanos de la Tercera Orden de San Francisco. 
Los portugueses analizados no desarrollaron una identidad cultural propia que los hubiese distinguido del resto de sus vecinos; vivieron integrados en la sociedad, sin que eso significara el olvido de la tierra de origen. Permaneció en ellos el carácter múltiple de su identidad: nacieron portugueses y morirían como tales en la ciudad de adopción, establecieron vínculos con la parroquia o barrio donde habían fijado su residencia, se relacionan con gentes de diversa naturaleza y grupo étnico, se integran a través del comercio y de las actividades productivas en el movimiento económico de la ciudad, y acuden a conventos, iglesias y hospitales que atendían, asimismo, a los españoles.

Fueron pocos los portugueses que optaron por formar parte de cofradías o hermandades, poco más de la quinta parte de los casos conocidos. ${ }^{67}$ Las cofradías en las que se integraron fueron de muy variada naturaleza y fundación, lo que permite sostener que no hubo en la Lima de aquel tiempo asociaciones de carácter nacional para el grupo de los lusos: ¿acaso puede entenderse esto como una estrategia utilizada por este colectivo para diluirse entre sus vecinos y externamente aparecer como auténticos cristianos, evitando así la persecución inquisitorial $?^{68}$ En el fondo del asunto creemos que hubo un proceso natural de integración con el medio y, como cristianos auténticos que eran, los portugueses se habrían esforzado por alcanzar la salvación del alma a través de los diversos medios presentados por la Iglesia, y en este contexto las cofradías y hermandades habrían representado uno de esos medios posibles de salvación.

Recibido el 24 de enero de 2017 Segunda versión 16 de julio de 2017 Aceptado el 2 de septiembre de 2017

67 Esta realidad coincide con el estudio de Truhan y Paniagua sobre los portugueses de Cuenca, de la Audiencia de Quito. De acuerdo con los autores los portugueses radicados allí «no mostraron mucho interés por las cofradías de la ciudad», primero porque «en Cuenca se carecía de aquellas de carácter profesional que había en otras ciudades como Quito y Guayaquil», y segundo porque «las de esta ciudad [...] respondían sobre todo a intereses eclesiásticos». Truhan y Paniagua, 1997, 215-218; Vila Vilar, 1979.

68 Esta hipótesis ha sido sostenida por algunos investigadores que han trabajado el tema de los portugueses judaizantes. Según ellos la pertenencia a una cofradía, el hecho de hacer testamento o el cumplir «sobradamente con la Iglesia a la hora de su muerte» habrían representado para los lusos una manifestación externa de su religiosidad, una farsa o una suerte de seguro que podían invocar en caso de necesidad, esto es, en caso de que se vieran involucrados en las denuncias del tribunal inquisitorial. Al respecto véase Truhan y Paniagua, 1997, 215-218; Vila Vilar, 1979. 


\section{Referencias bibliográficas}

Álvarez Santos, Javier, «Estrategias de movilidad y de integración de la comunidad lusa en Tenerife en tiempos de la Unión Ibérica», Vegueta. Anuario de la Facultad de Geografía e Historia, 16, Las Palmas de Gran Canaria, 2016, 387-401.

Campos y Fernández de Sevilla, F. Javier (ed.), Catálogo de Cofradías del Archivo del Arzobispado de Lima, Madrid, Instituto Escurialense de Investigaciones Históricas y Artísticas, 2014 (disponible en http://www.javiercampos.com/ files/Catalogo\%20Cofradias\%20Archivo\%20Arzobispal\%20Lima.pdf).

Celestino, Olinda y Meyers, Albert, Las cofradías en el Perú: región central, Frankfurt-Main, Klaus Dietor Vervuert, 1981.

Cobo, Bernabé, Historia de la fundación de Lima, con biografía del autor y notas de M. Gonzáles de la Rosa, Lima, Imprenta Liberal, 1882.

Corilla Melchor, Ciro, «Cofradías en la ciudad de Lima, siglos XVI y XVII: racismo y conflictos étnicos», en Carrillo, Ana Cecilia et al., Etnicidad y discriminación racial en la historia del Perú, Lima, Pontificia Universidad Católica del Perú, Instituto Riva Agüero, Banco Mundial, 2002, 11-34.

Garland Ponce, Beatriz, «Las cofradías en Lima durante la colonia. Una primera aproximación», en Ramos, Gabriela (comp.), La venida del reino. Religión, evangelización y cultura en América. Siglos XVI-XX, Cusco, Centro de Estudios Regionales Andinos Bartolomé de las Casas, 1994, 199-228.

Gil Pujol, Xavier, «Ciudad, comunicación y concordia en España e Hispanoamérica durante el Renacimiento», TEMPUS. Revista en Historia General, 4, Medellín (Colombia), 2016, 47-71.

Lévano Medina, Diego E., «Organización y funcionalidad de las cofradías urbanas, siglo XVII», Revista del Archivo General de la Nación, 24, Lima, 2002, 77-118.

Lévano Medina, Diego E. y Montoya Estrada, Kelly (comps.), Corporaciones Religiosas y evangelización en Iberoamérica. Siglos XVI-XVIII, Lima, 2010.

Lohmann Villena, Guillermo, «La ilustre hermandad de Nuestra Señora de Aránzazu de Lima», en Arana Pérez, Ignacio (coord.), Los vascos y América. Ideas, hechos, hombres, Madrid, Gela. 1990, 203-213.

Medina, José Toribio, Historia del Tribunal del Santo Oficio de la Inquisición de Lima (1569-1820), Santiago de Chile, Imprenta Gutenberg, 1887, tomo II.

Montesinos, Fernando, Auto de la fe celebrado en Lima a 23 de enero de 1639, Lima, Pedro de Cabrera, 1639.

Moreno Cebrián, Alfredo y Sullón Barreto, Gleydi, «Somos cristianos, no judíos. Portugueses en la "gran complicidad" y el auto de fe limeño de 1639», Boletín del Instituto Riva Agüero, 37, Lima, 2014, 1-29.

Paniagua Pérez, Jesús, «Cofradías limeñas: San Eloy y la Misericordia (15971733)», Anuario de Estudios Americanos, 52, 1, Sevilla, 1995, 13-35. 
Palomo, Federico, A Contra-Reforma em Portugal, 1540-1700, Lisboa, Livros Horizonte, 2006.

Pérez-Mallaína, Pablo Emilio y Torres Ramírez, Bibiano, La Armada del Mar del Sur, Sevilla, Escuela de Estudios Hispano-Americanos, CSIC, 1987.

Ponce Leiva, Pilar y Amadori, Arrigo, «Redes sociales y ejercicio del poder en la América Hispana: consideraciones teóricas y propuestas de análisis», Revista Complutense de Historia de América, 34, Madrid, 2008, 15-42.

Puente Brunke, José de la, «Apuntes sobre la Hermandad de Nuestra Señora de Aránzazu en la Lima virreinal», Studia Limensia. Revista de Humanidades, 1, 2002, 92-99.

Pulido Serrano, Juan Ignacio, «Hermandades portuguesas fuera de Portugal (siglos XVI-XVIII)», en Ventura, Maria da Graça Mateus (ed.), O Associativismo. Das Confrarias e Irmandades aos Movimentos Sociais Contemporăneos, Lisboa, Edições Colibri, Instituto de Cultura Ibero-Atlântica, 2006, 29-49.

Pulido Serrano, Juan Ignacio, «Vida y milagros de san Antonio de Padua de Mateo Alemán: Razones de una obra literaria», en Guillemont, Michèlle y Vila, Juan Diego (coords.), Para leer el Guzmán de Alfarache y otros textos de Mateo Alemán, Buenos Aires, Eudeba, 2015, 35-62.

Quiroz, Francisco, Gremios, razas y libertad de industria. Lima colonial, Lima, Facultad de Ciencias Sociales, Universidad Nacional Mayor de San Marcos, 1995.

Quiroz, Francisco, Artesanos y manufactureros en Lima colonial, Lima, Banco Central de Reserva del Perú, Instituto de Estudios Peruanos, 2008.

Rodríguez Mateos, Joaquín, «Las cofradías de Perú en la modernidad y el espíritu de la contrarreforma», Anuario de Estudios Americanos, 52, 2, Sevilla, 1995, 15-43.

Santos, Isabel Dâmaso, «San Antonio en el mundo hispánico. Arte, Literatura, Cultura», en Civil, Pierre y Crémoux, François, Actas del XVI Congreso de la Asociación Internacional de Hispanistas (París, 2007), Madrid, Iberoamericana, 2010, vol. 2 [CD-ROM], https://cvc.cervantes.es/literatura/aih/pdf/16/ aih_16_2_073.pdf

Sullón Barreto, Gleydi, Extranjeros integrados. Portugueses en la Lima virreinal, 1570-1680, Madrid, Consejo Superior de Investigaciones Científicas, 2016.

Truhan, Deborah y Paniagua Pérez, Jesús, «Los portugueses en América. La ciudad de Cuenca del Perú (1580-1640)», Revista de Ciências Históricas, XII, Universidad Portucalense, 1997, 201-220.

Valladares, Rafael, «Por toda la tierra». España y Portugal: globalización y ruptura (1580-1700), Lisboa, Centro de História d'Aquém e d'Além-Mar, Faculdade de Ciências Sociais e Humanas, Universidade NOVA de Lisboa, Universidade dos Açores, 2016.

Vargas Ugarte, Rubén, Historia de la Iglesia en el Perú (1511-1568), vol. 1, Lima, Imprenta Santa María, 1953. 


\section{GLEYDI SULLÓN BARRETO}

Vega Jácome, Walter, «Cofradías en el Perú colonial: una aproximación bibliográfica», Diálogos, 1, 1999, 137-152.

Ventura, Maria da Graça A. Mateus, Portugueses no Peru ao Tempo da União Ibérica: mobilidade, cumplicidades e vivência, Lisboa, Imprensa Nacional, Casa da Moeda, 2005, 3 v.

Vila Vilar, Enriqueta, «Extranjeros en Cartagena (1593-1630)», Jahrbuch für Geschichte Lateinamerikas, 16, 1979, 147-184. 